\title{
DETEKSI DINI GEJALA STROKE SEBAGAI BAGIAN DARI PROGRAM BINA KELUARGA LANSIA DI KABUPATEN MALANG
}

\author{
Ira Rahmawati ${ }^{\text {a* }}$; Lingling Marinda Palupi ${ }^{b}$ \\ a, $b$ Jurusan Keperawatan ; Poltekkes Kemenkes Malang; \\ Jl. Ijen besar no 77C; Klojen; Malang
}

\begin{abstract}
Abstrak
Kegiatan pengabdian masyarakat telah dilakukan secara rutin oleh setiap dosen di lingkungan Poltekkes Kemenkes Malang. Meningkatkan usia harapan hidup di Indonesia akan diringi dengan meningkatnya jumlah lansia dan insiden penyakit tidak menular salah satunya adalah stroke. Kemampuan untuk dapat mengenali gejala stroke secara dini dapat mempercepat pelayanan kesehatan yang dibutuhkan dan memperkecil resiko kematian dan kecacatan. Sosialisasi mengenai deteksi dini gejala stroke ini dilakukan kepada masyarat di kampung KB di dua kecamatan yaitu Kecamatan Kepanjen dan Kecamatan Pakis Kabupaten Malang sebagai bagian dari program ketahanan keluarga. Kegiatan ini dilakukan pada tanggal 9 Desember 2019. Sebanyak 55 orang peserta yang terdiri dari kader Bina Keluarga Lansia dan tokoh masyarakat terlibat dalam kegiatan ini. Tujuan dari kegiatan ini adalah meningkatkan pemahaman masyarakat mengenai gejala dini stroke dengan sosialisasi slogan yang mudah diingat yaitu “Se Ge Ra Ke RS". Kegiatan lain yang dilakukan yaitu demonstrasi dan pelatihan pemeriksaan fisik sederhana untuk mengenali salah satu gejala stroke yang sering timbul, yaitu hemiparesis.
\end{abstract}

Kata kunci: Stroke, Lansia; Deteksi dini, Bina Keluarga Lansia,

\begin{abstract}
[Early Detection Of Stroke Symptoms As Part Of The Elderly Development Program In Malang District] Knowledge transfer for community development has been regularly conducted by all lecturer of the Health Polytechnic Malang, Ministry of Health Indonesia. As the Life expectancy increases, the incidence of degenerative diseases, such as stroke is expected to spike. Early diagnosis is pivotal in stroke management. Early identification of stroke using a validated stroke-screening tool may facilitate a timely initiation of the appropriate treatment such as a thrombolytic therapy. This program aimed to educate health leaders in the community about stroke screening tools that have been developed by the Ministry of Health of Republic of Indonesia, namely "Se Ge Ra Ke RS". The project was conducted in two kampung KB in Malang, namely Kecamatan Kepanjen and Pakis on December 9th 2019 and attended by 55 health leaders in the community. A simple physical assessment to determine the presence of hemiparesis caused by stroke was also demonstrated.
\end{abstract}

Keywords: Stroke, elderly, stroke screening tools, hemiparesis

\section{Pendahuluan}

Pembangunan kesehatan di Indonesia diarahkan pada peningkatan kualitas hidup manusia dan masyarakat termasuk masyarakat

\footnotetext{
*) Correspondence Author (Ira Rahmawati)

E-mail: irarahmawati.polkesma@gmail.com
}

usia lanjut. Keberhasilan pembangunan dalam bidang kesehatan menyebabkan meningkatnya usia harapan hidup (UHH) pada tahun 2010 adalah 64,5 tahun dengan jumlah populasi lansia adalah $7,56 \%$ dan satu tahun kemudian meningkat menjadi 69,65 tahun dengan jumlah 
penduduk lansia sebanyak 7,58\% (DepKes, 2013). Hasil sensus penduduk tahun 2010 menunjukkan bahwa Indonesia termasuk lima besar negara dengan jumlah penduduk lanjut usia terbanyak di dunia, yang mencapai 18,1 juta jiwa atau 7,6 persen dari total penduduk. Badan Pusat Statistik (2014) memproyeksikan, jumlah penduduk yang berusia $>60$ tahun diperkirakan akan meningkat menjadi 27,1 juta jiwa pada tahun 2020, menjadi 33,7 juta jiwa pada tahun 2025 dan 48,2 juta jiwa tahun 2035. Jumlah lansia perempuan lebih besar daripada laki-laki, yaitu 10,77 juta lansia perempuan dibandingkan 9,47 juta lansia laki-laki, adapun lansia yang tinggal di pedesaan sebanyak 10,87 juta jiwa, lebih banyak daripada lansia yang tinggal di perkotaan yaitu 9,37 juta jiwa (Kemenkes, 2016; Statistik, 2014).

Meningkatnya jumlah penduduk lanjut usia akan diiringi dengan meningkatkan kejadian penyakit degenarif seperti penyakit jantung dan pembuluh darah, diabetes mellitus dan stroke. Resiko untuk mengalami stroke khususnya, akan meningkat dua kali lipat pada usia $>55$ tahun baik pada laki-laki maupun perempuan (Michael \& Shaughnessy, 2006; Suiraoka, 2012). Selain itu, meningkatnya usia akan berdampak pada berbagai aspek kehidupan lansia yaitu aspek fisiologis, psikologis, social dan ekonomi.

Sebagaimana yang telah dikemukaan diatas bahwa dengan bertambahnya usia, sel-sel tubuh mengalami kemunduran karena proses penuaan yang dapat berakibat pada kelemahan organ, kemunduran fisik, timbulnya berbagai macam penyakit (Efendi \& Makhfudli, 2009). Stroke adalah salah satu gangguan yang paling banyak dijumpai pada lansia. Hal ini berhubungan dengan menurunnya fungsi endothelial pembuluh darah arteri, perubahan metabolik dan meningkatnya kejadian atherosklerosis pada lansia (Tesauro et al., 2017).

Stroke merupakan salah satu penyakit penyebab kematian dan kecacatan paling tinggi didunia serta mempunyai dampak ekonomi yang signifikan (Feigin et al., 2019; Randolph, 2016). Menurut data Kementerian Kesehatan Republik Indonesia, terdapat 500.000 kasus stroke di Indonesia setiap tahun yang menyebabkan disabilitas dan 12.500 orang meninggal dunia (Ministry of Health Indonesia, 2018).

Keterlambatan dalam penanganan stroke dapat meningkatkan resiko kematian dan kecatatan yang permanen. Karena itu, salah satu aspek penting dari penatalaksanaan stroke adalah identifikasi gejala stroke secara tepat dan dini serta kemudahan akses dalam menentukan jenis stroke dan terapi trombolitik jika memenuhi kriteria (Marler et al., 2000). Untuk dapat mengenali gejala stroke secara dini, banyak metode skrining yang telah dikembangkan dan mudah digunakan di pre hospital setting diantaranya yaitu Face, Arm, Speech Test (FAST), Cincinnati Prehospital Stroke Scale (CPSS), PreHospital Ambulance Stroke Test (PreHAST) dan Recognition of Stroke in the Emergency Room (ROSIER) (Walker Gregory, Zhelev, Henschke, Fridhandler, \& Yip, 2019).

Kementerian Kesehatan Republik Indonesia telah pula mengembangkan metode deteksi dini gejala stroke yang mudah diikuti oleh masyarakat yaitu slogan "SeGeRa Ke RS". Yaitu, senyum tidak simetris, gerak anggota tubuh sebelah melemah tiba-tiba, bicara tiba-tiba pelo, kebas atau kesemutan separuh tubuh, rabun atau pandangan kabur hanya pada salah satu mata secara tiba-tiba dan sakit kepala hebat yang muncul secara tiba-tiba. Sakit kepala hebat yang paling berat yang pernah dirasakan ini kemungkinan besar menunjukkan adanya stroke hemoragik yang disebabkan aneurisma yang ruptur (Barritt, Miller, Davagnanam, \& Matharu, 2016).

Dengan meningkatkan pengetahuan kader Bina Keluarga Lansia (BKL) mengenai gejala dini stroke, diharapkan para kader dapat berperan sebagai garda terdepan dalam meningkatkan kecepatan deteksi dan penataaksanaan stroke. Selain itu, diharapkan juga bahwa para kader BKL dapat meneruskan pengetahuan ini kepada masyarakat luas sehingga menignkatkan ketahanan masyarakat dalam melaksanakan gerakan masyarakat hidup sehat (Rahmawaty, Handayani, Sari, \& Rahmawati, 2019).

\section{Metode}

Pengabdian masyarakat ini dilakukan pada tanggal 9 Desember 2019 di dua tempat yang merupakan kampung KB yaitu balai desa Panggungrejo Kecamatan Kepanjen dan balai desa Bunut Wetan Kecamatan Pakis Kabupaten Malang. Peserta yang hadir sebanyak 55 orang yang terdiri dari kader Bina Keluarga Lansia (BKL), petugas balai desa dan perwakilan 
BKKBN kab. Malang. Dilakukan Sosialisasi deteksi dini gejala stroke dengan slogan SeGeRa Ke RS dilanjutkan dengan demonstrasi pemeriksaan fisik sederhana untuk mengenali gejala stroke.

Penilaian keberhasilan kegiatan ini dilihat dari jumlah kader bina kesehatan lansia yang menghadiri kegiatan dan kemampuan mendemonstrasikan kembali pemeriksaan fisik sederhana untuk mendeteksi adanya kelemahan anggota gerak yang dapat diakibatkan oleh stroke serta tanya jawab dan diskusi yang dilakukan selama pemberian materi.

\section{Hasil dan Pembahasan}

Kegiatan pengabdian kepada masyarakat ini dilaksanakan pada tanggal 9 Desember di dua Kampung KB sekaligus yaitu Kecamatan Kepanjen dan Kecamatan Pakis, Kabupaten Malang. Tepatnya di balai desa Panggung rejo dan Balai Desa Bunut Wetan. Adapun kegiatan yang dilakukan adalah sosialisasi Slogan SeGeRa Ke RS sebagai metode mendeteksi gejala stroke secara dini, dilanjutkan dengan demonstrasi pemeriksaan fisik sederhana untuk memastikan gejala stroke. Adapun materi selengkapnya adalah sebagai berikut:

a. Pengertian stroke dan jenis stroke

b. Gejala stroke dan cara mendeteksi gejala stroke secara dini

c. Faktor resiko stroke dan gerakan masyarakat hidup sehat untuk mencegah terjadinya hipertensi dan stroke

d. Pertolongan pertama pada individu yang mempunyai gejala stroke

e. Peran keluarga dalam rehabilitasi pasca stroke.

Selain Pemberian materi tersebut, dilakukan juga demonstrasi pemeriksaan fisik sederhana untuk memastikan gejala dini stroke, yaitu melakukan pemeriksaan kekuatan otot ekstremitas sederhana untuk memastikan adanya hemiparesis.

Kegiatan ini dihadiri lebih dari $90 \%$ kader bina kesehatan lansia di dua kampung KB di Kabupaten malang. Peserta tampak antusias dalam mengikuti materi dan demontrasi yang diberikan. Peserta juga terlibat aktif dalam diskusi dan tanya jawab yang berlangsung setelah pemberian materi. Beberapa peserta mengatakan pernah memiliki anggota keluarga atau menyaksikan tetangga yang mengalami gejala stroke. Delapan orang kader yang ditunjuk secara acak dapat mendemonstrasikan dengan baik metode pemeriksaan fisik sederhana untuk mendeteksi adanya kelemahan anggota gerak yang dapat diakibatkan oleh stroke. Kegiatan ini selanjutnya akan dilakukan disemua kampung KB yang ada di Kabupaten Malang bekerja sama dengan kantor BKKBN Kab. Malang.

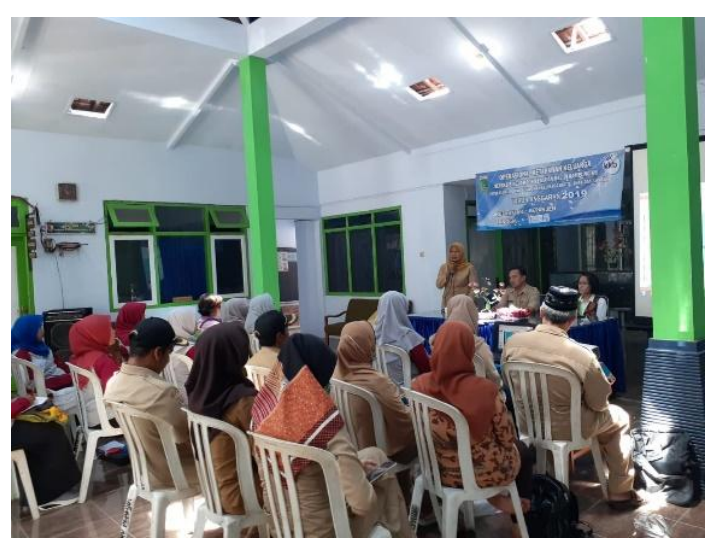

Gambar 1. Peserta kegiatan sosialisasi gejala dini stroke SeGeRa Ke RS di Kec. Kepanjen, Kab. Malang

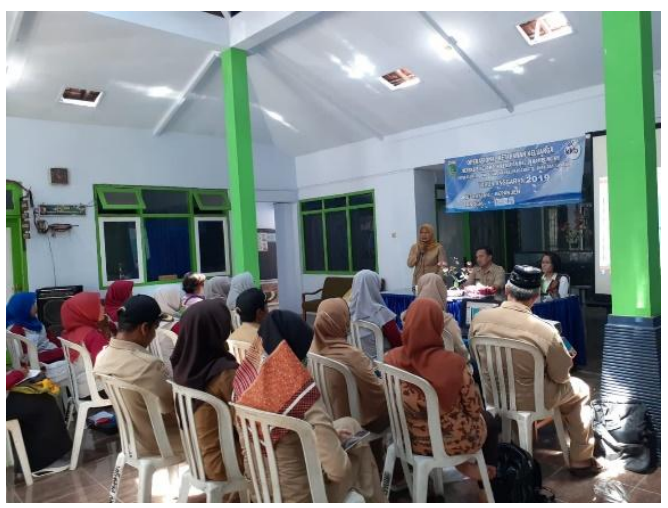

Gambar 2. Sambutan dari perwakilan kantor BKKBN kab.malang.

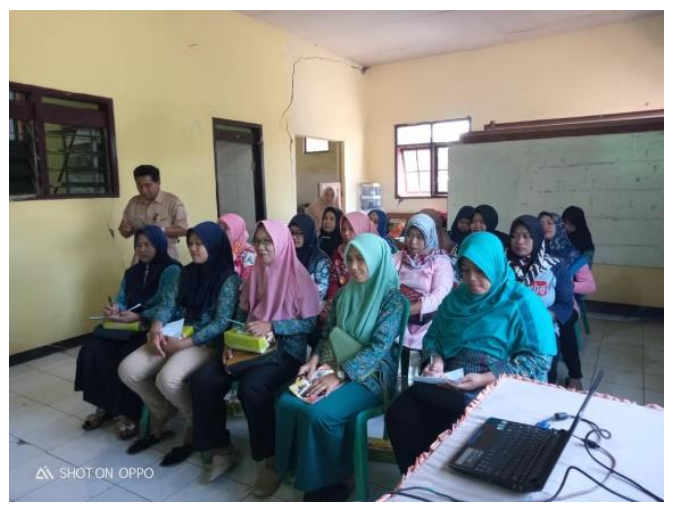


Gambar 3. Peserta kegiatan sosialisasi gejala dini stroke SeGeRa Ke RS di Kec. Pakis, Kab. Malang

Deteksi dini gejala stroke harus diiringi dengan penatalaksanaan yang tepat. Pasien dengan gejala stroke harus dibawa ke Rumah Sakit yang paling tidak mempunyai fasilitas CT-Scan. Kami menekankan bahwa ketika seseorang mengalami gejala stroke, maka keluarga dibantu kader kesehatan setempat harus menghindari membawa pasien ke Puskesmas, tetapi langsung ke RS daerah setempat yang mempunyai fasilitas CT scan. Dengan penanganan yang cepat dan tepat, diharapkan dapat mengurangi resiko kecacatan permanen dan kematian. Hal ini sesuai dengan prinsip "time is brain" dalam penatalaksanaan stroke (Saver Jeffrey, 2006).

Seseorang yang pernah mengalami stroke memiliki kecenderungan untuk mengalami stroke berulang, terutama apabila faktor risiko yang dialami tidak ditanggulangi dengan benar. Perlu adanya prevensi sekunder yang meliputi gaya hidup sehat serta pengendalian faktor risiko untuk mencegah terjadinya serangan stroke berulang pada penderita yang pernah mengalami kejadian stroke (Yulianto, 2011). Oleh karena itu merupakan suatu tantangan bagi kita untuk mengupayakan lansia tetap memiliki kesiapan fisik dan mental serta adanya peningkatan perilaku hidup sehat sehingga menjadi sumber daya manusia yang optimal. Sehubungan dengan upaya komprehensif ini diperlukan adanya kerjasama antara masyarakat, petugas kesehatan, dan instansi yang berkaitan melalui pengadaan berbagai kegiatan ceramah, symposium, lokakarya, penyuluhan dan penyediaan fasilitas kesehatan bagi masyarakat lansia.

Program BKL (Bina Keluarga Lansia) merupakan suatu program melibatkan keluarga yang memiliki lansia untuk mengetahui, memahami, dan mampu membina kondisi dan masalah yang dihadapi lansia. Pada program BKL dituntut peran keluarga dalam memenuhi kebutuhan lansia diantaranya berupa pemenuhan kebutuhan ekonomi, psikososial dan kesehatan fisik, nutrisi makanan, serta berupaya mendorong lansia agar tetap menanamkan perilaku hidup sehat sehingga lansia tetap sehat bugar dan tidak menjadi beban (Koordinasi Keluarga Berencana Nasional, 2006). Pembinaan kesehatan lansia melalui wadah BKL merupakan salah satu pendekatan dari program perawatan kesehatan masyarakat (Public Health Nursing) yang ditujukan untuk meningkatkan jangkauan dan pemerataan pelayanan kesehatan kepada masyarakat. Dengan adanya pembinaan melalui program BKL pada periode bulan Desember 2019.

Pengetahuan tentang identifikasi dini gejala stroke beserta kemampuan untuk melakukan pemeriksaan fisik sederhana telah diberikan dan diterima dengan baik oleh kader BKL di kampung KB. Selanjutnya kegiatan yang bersifat rutin akan dilakukan setiap bulan dengan peserta yang lebih luas yaitu masyarakat di kampung KB terutama yang memiliki anggota keluarga lansia. Kegiatan rutin ini dilakukan oleh para kader BKL di kampung KB yang difasilitasi dan disupervisi oleh kantor BKKBN Kab. Malang bekerja sama dengan Puskesmas Kecamatan Kepanjen dan perwakilan dari Prodi Keperawatan Poltekkes Kemenkes Malang. Kegiatan-kegiatan yang dilakukan berfokus pada peningkatan ketahanan keluarga dalam meningkatkan kualitas hidup lansia dan masyarakat secara umum.

\section{Simpulan dan Saran}

Identifikasi gejala dini stroke dapat mempercepat penatalaksanaan stroke di fasilitas kesehatan yang memadai sehingga dapat menurunkan resiko kematian dan kecacatan yang permanen. Lansia merupakan kelompok yang paling rentan mengalami stroke. Pencegahan dan identifikasi dini gejala stroke perlu melibatkan keluarga dan setiap unsur masyarakat. Peningkatan pengetahuan dan pelatihan kader BKL merupakan salah satu langkah strategis dalam rangka meningkatkan kesiap-siagaan masyarakat dalam mendeteksi gelaja stroke. Dengan kerjasama semua lapisan masyarakat diharapkan kita dapat meningkatkan kualitas hidup lansia di lingkungan tempat tinggal kita.

\section{Ucapan Terima Kasih}

Terima kasih diucapkan kepada seluruh kader Bina Keluarga Lansia (BKL) di Kecamatan Kepanjen dan Pakis Kabupaten Malang, Kepala kantor BKKBN Kabupaten Malang beserta jajarannya , Kepala Desa Panggungrejo dan Bunut Wetan beserta jajarannya, Kaprodi Keperawatan Lawang beserta dosen dan tenaga 
kependidikan, serta semua pihak yang terllibat dalam kegiatan pengabdian masyarakat ini.

\section{Daftar Pustaka}

Barritt, A., Miller, S., Davagnanam, I., \& Matharu, M. (2016). Rapid diagnosis vital in thunderclap headache. The Practitioner, 260(1792), 23-28, 23.

DepKes, D. K. R. I. (2013). Pedoman Pembinaan Kesehatan Usia Lanjut Bagi petugas Kesehatan. Jakarta.

Efendi, E., \& Makhfudli. (2009). Keperawatan Kesehatan Komunitas: Teori dan Praktik dalam Keperawatan. Jakarta: Salemba Medika.

Feigin, V., Nichols, E., Alam T, Bannick, M., Beghi, E., \& Blake, N. (2019). Global, regional, and national burden of neurological disorders, 1990-2016: a systematic analysis for the Global Burden of Disease Study 2016. Lancet Neurol, 18(5), 459-480. doi: 10.1016/s1474-4422(18)30499-x

Kemenkes. (2016). PMK No.25 Tentang Rencana Aksi Nasional Lanjut Usia Tahun 2016.

Koordinasi Keluarga Berencana Nasional, B. (2006). Modul Bina Keluarga Lansia. Medan.

Marler, J. R., Tilley, B. C., Lu, M., Brott, T. G., Lyden, P. C., Grotta, J. C., . . . Kwiatkowski, T. P. (2000). Early stroke treatment associated with better outcome. Neurology, 55(11), 1649.

Michael, K. M., \& Shaughnessy, M. (2006). Stroke prevention and management in older adults. J Cardiovasc Nurs, 21(5 Suppl 1), S21-26. doi: 10.1097/00005082-200609001-00006
Ministry of Health Indonesia. (2018). Pusat Data dan Informasi Kesehatan Kementerian Kesehatan RI. Indonesia.

Rahmawaty, E., Handayani, S., Sari, M. H. N., \& Rahmawati, I. (2019). SOSIALISASI DAN HARMONISASI GERAKAN MASYARAKAT HIDUP SEHAT (GERMAS) DAN PROGRAM INDONESIA SEHAT DENGAN PENDEKATAN KELUARGA (PIS-PK) DI KOTA SUKABUMI. LINK, 15(1), 27-31.

Randolph, S. A. (2016). Ischemic Stroke. Workplace Health Saf, 64(9), 444. doi: $10.1177 / 2165079916665400$

Saver Jeffrey, L. (2006). Time Is Brain-Quantified. Stroke, 37(1), 263-266. doi:

10.1161/01.STR.0000196957.55928.ab

Statistik, B. P. (2014). Statistik Penduduk Lanjut Usia. Jakarta.

Suiraoka. (2012). Penyakit degenerative. Yogyakarta, Indonesia: Nuha Medika

Tesauro, M., Mauriello, A., Rovella, V., Annicchiarico-Petruzzelli, M., Cardillo, C., Melino, G., \& Di Daniele, N. (2017). Arterial ageing: from endothelial dysfunction to vascular calcification. Journal of Internal Medicine, 281(5), 471-482. doi: 10.1111/joim.12605

Walker Gregory, B., Zhelev, Z., Henschke, N., Fridhandler, J., \& Yip, S. (2019). Prehospital Stroke Scales as Screening Tools for Early Identification of Stroke and Transient Ischemic Attack. Stroke, 50(10), e285-e286. doi: 10.1161/STROKEAHA.119.026527

Yulianto, A. (2011). Mengapa Stroke Menyerang Usia Muda? Yogyakarta: Javalitera. 